\begin{tabular}{|l|l|l||}
\hline \multicolumn{2}{|c|}{ PublisherInfo } \\
\hline \hline PublisherName & $:$ & BioMed Central \\
\hline \hline PublisherLocation & $:$ & London \\
\hline \hline PublisherImprintName & $:$ & BioMed Central \\
\hline \hline
\end{tabular}

\title{
Degrading mutations
}

\begin{tabular}{|l|l|l||}
\hline \multicolumn{2}{|c|}{ ArticleInfo } \\
\hline \hline ArticleID & $:$ & 4134 \\
\hline \hline ArticleDOI & $:$ & $10.1186 /$ gb-spotlight-20010702-01 \\
\hline \hline ArticleCitationID & $:$ & spotlight-20010702-01 \\
\hline \hline ArticleSequenceNumber & $:$ & 205 \\
\hline \hline ArticleCategory & $:$ & Research news \\
\hline \hline ArticleFirstPage & $:$ & 1 \\
\hline \hline ArticleLastPage & $:$ & 2 \\
\hline \hline & & RegistrationDate : 2001-07-02 \\
ArticleHistory & $:$ & OnlineDate $\quad$ 2001-07-02 \\
\hline \hline ArticleCopyright & $:$ & BioMed Central Ltd2001 \\
\hline \hline ArticleGrants & $:$ & \\
\hline \hline ArticleContext & $:$ & 130592211 \\
\hline \hline
\end{tabular}




\section{Jonathan B Weitzman}

Email: jonathanweitzman@hotmail.com

Inherited osteolysis (also known as vanishing bone syndrome) is characterized by abnormal destruction and resorption of bone. In the July issue of Nature Genetics, Martignetti et al. identify mutations in the matrix metalloproteinase 2 gene (MMP2) in several Saudi Arabian families with osteolysis (Nature Genetics 2001, 28:261-265). They performed a genome-wide search for homozygous-by-descent microsatellite markers, in order to hone in on a region of chromosome 16q12 that includes the MMP2 gene. MMP2 enzymatic activity could not be detected in serum or cultured skin fibroblasts from these patients. Martignetti et al. identified two homoallelic MMP2 mutations: a missense mutation $(\mathrm{R} 101 \mathrm{H})$ within the prodomain and a non-sense mutation (Y244X) that deletes the catalytic sites. The authors suggest that the unexpected role of MMP2 in osteolysis may involve deregulated extracelluar matrix breakdown leading to an imbalance between bone synthesis and resorption.

\section{References}

1. Osteolysis, hereditary multicentric, [http://www.ncbi.nlm.nih.gov:80/entrez/ dispomim.cgi?id=259600]

2. Nature Genetics, [http://genetics.nature.com]

3. New form of idiopathic osteolysis: nodulosis, arthropathy and osteolysis (NAO) syndrome.

4. Completion of the primary structure of the human type IV collagenase preproenzyme and assignment of the gene (CLG4) to the q21 region of chromosome 16.

This PDF file was created after publication. 